\title{
The path of non-conformity
}

\author{
Kamran Abbasi international editor, The BMJ
}

What is courage? Is courage possible without fear? Nelson Mandela believed that courage was not the absence of fear but the triumph over it: "The brave man is not he who does not feel afraid, but he who conquers that fear." Each news report brings us stories of courage, from the inhumanity of Europe's battle trenches of a century ago to the humanitarian and public health crisis in Gaza today, and yet no statesman of Mandela's calibre is able to guide us to a less fearful place.

Courage is also treating patients with Ebola disease, writes Margaret McCartney, who sympathises with the fear that health workers might feel and admires those who continue to risk their lives to save patients (BMJ 2014;349:g4987, doi:10.1136/bmj. g4987). "I am afraid for my life," said one such doctor before his death from the disease, "because I cherish my life." Ebola has now spread across four densely populated countries in west Africa in less than six months, killing over 700 people, as Sophie Arie's feature describes (BMJ 2014;349:g4997, doi:10.1136/ bmj.g4997). Aid agencies warn that the outbreak is out of control and that air travel could spread the virus almost anywhere.

People seeking assisted dying may cherish life but are now willing to accept death. A recent editorial (BMJ 2014;349:g4349, doi:10.1136/bmj.g4349) led to a debate on the merits of The $B M J$ declaring a stance on this topic. Assisted dying goes against why many of us become doctors, says one reader ( $B M J$ 2014;349:g4965, doi:10.1136/bmj.g4965). The BMJ's position will create publication bias, because opponents of assisted dying will no longer submit articles, argues another (BMJ

2014;349:g4948, doi:10.1136/bmj.g4948). The volume of letters in this issue and on thebmj.com suggests that, if anything, critics of The BMJ's stance have been encouraged to write in. "The journal hasn't closed its mind to opposing points of view," the editorialists reply (BMJ 2014;349:g4949, doi:10.1136/bmj. g4949). "The debate is far from over, and we would like it to be reflected in our pages."

Like courage, debate is everywhere in this week's issue. The Oxford University professor Rory Collins demanded retraction of two articles that contained a factual error overestimating the level of side effects of statins (BMJ 2013;347:f6123, doi:10. 1136/bmj.f6123; BMJ 2013;347:f6340, doi:10.1136/bmj.f6340). The error was corrected, but Collins still wanted full retraction.

The BMJ convened a panel to independently investigate our handling of the articles, Collins's complaint, and whether or not retraction was appropriate. The panel reported last week after two months of deliberation. It endorsed The BMJ's decision not to retract the articles, expressed surprise at Collins's reluctance to debate publicly in The $B M J$, and suggested improvements to The BMJ's editorial processes and handling of corrections. The $B M J$ will act on this advice, writes its editor in chief, Fiona Godlee (BMJ 2014;349:g5038, doi:10.1136/bmj. g5038), and will continue to publish on both sides of the statins debate and increase calls for the release of trial data so that independent assessments of benefits and risks of statin treatment can be made. The full report of the independent panel, the submissions it received, and an interactive timeline of events are available online (thebmj.com/statins).

What does all this heavyweight debate mean for Mr Lowrisk, keen on golf but confused by statins (BMJ 2014;349:g5007, doi:10.1136/bmj.g5007)? Or even a South Asian professor in Scotland who is at risk of coronary heart disease but able to understand numbers needed to treat (BMJ 2014;349:g4980, doi:10.1136/bmj.g4980)? Evidence is all well and good, concludes Raj Bhopal, but the values and beliefs of the medical profession will probably wield the most influence in the public's decision making. Indeed, power over patients and authors comes easily to doctors and editors. Courage is harder and it tends, like Mandela, not to choose the path of conformity.

Follow Kamran Abbasi on Twitter @KamranAbbasi 